\title{
Grade 12 Learners' Understanding of Chemical Reactions
}

\author{
Israel Kibirige ${ }^{1^{*}}$ \\ Mashupye Alfred Masemola² \\ 1,2University of Limpopo, School of Education. Department of Mathematics, \\ Science and Technology Education (DMSTE), South Africa \\ ${ }^{*}$ Corresponding author: Israel.Kibirige@ul.ac.za
}

\section{Doi:10.5901/mjss.2014.v5n8p290}

\begin{abstract}
The purpose of the research was to investigate grade 12 learners' understanding of chemical reactions in order to improve teaching and learning. A sample of 40 grade12 learners was selected from a school in Lobethal circuit. A 5-point Likert questionnaire with 20-items was used to collect data. The study revealed that the respondents had different perspectives about chemical reactions. Some respondents had difficulties in understanding bonds breaking during chemical reactions, whilst others perceived bond formation as the exchange of electrons between atoms. The findings from this study may be useful to the learners in understanding chemical reactions better and to the teachers as well as policy makers to create environment for learning. The study recommends strategies to use in order to overcome such learning difficulties in understanding chemical reactions.
\end{abstract}

Keywords: Chemical reactions, learners' understanding, practical work, bond breaking and formation

\section{Introduction}

Chemical reactions are important components of practical work in chemistry. Practical work involves the execution of a procedure for solving a problem, by way of drawing conclusions from empirical observations (Millar \& Abrahams 2009, Millar 2011). The aim of practical work is to develop manipulative, investigative and problem solving skills in learners (Millar 2010; Abrahams \& Reiss 2012). Learners are given the apparatus to use in order to carry out investigations which help them to solve a particular problem. Dekkers (1997: 101) contends that: "...Practical work can create a suitable context for developing creative thinking, communication and cooperation skills...". This implies that through practical work learners are able to work together to make their own judgments. In primary school teaching of chemistry practical work, learners are introduced to experiments through carrying out chemical reactions by themselves or through teacher demonstrations. Energy and bond formation are not introduced to them until they reach high school level. At high school level, they are introduced to the nature of chemical bonds and the associated ideas of chemical energetics (Boo, 1998). This creates a lot of problems to learners because they do not have the foundation of these concepts. Krajcik (1991), for instance, indicated that learners do not understand that in chemical reactions atoms and molecules comprise substances that recombine to create new molecules. They do not know that during chemical reactions, old bonds between atoms and molecules are broken and new ones are formed. Actually, they have difficulties in understanding how breaking and forming bonds takes place in chemical reactions.

During the process of breaking and forming of bonds, energy is either given off or absorbed in the form of heat or light (Brady and Holum, 1996). For example, when a sample of metallic magnesium is burned in air, magnesium combines with oxygen from air to form magnesium oxide. This chemical reaction between magnesium and oxygen is accompanied by the release of energy in the form of heat and light. Driver (1985) and Gabel (1993) indicate that focusing on the particulate nature of matter is helpful in developing learners' understanding of difficult concepts. Based on these difficulties, it was necessary to investigate and address learners' understanding of chemical reactions. The study aimed at identifying learners' understanding of chemiscal ractions and to develop strategies to use the knowledge of chemical reactions in solving real life problems.

\section{Literature Review}

Research has shown that learners have a number of difficulties with chemical reactions, conservation of mass and the 
particulate nature of matter (Ahtee \& Varjola, 1998). Learners often confuse physical change with chemical change (Ahtee \& Varjola, 1998). They do not understand that in chemical reactions, atoms and molecules comprise substances that recombine to create new molecules and thus new substances (Krajcik, 1991). Furthermore, chemical equations are representations of dynamic interactive processes and a chemical equation is used to represent chemical changes taking place during the reactions to form products (Krajcik, 1991). These reactions may have an affective domain on learners.

For instance, Reynolds \& Walberg (1991) in Malawi identified learners` aptitude, quality and quantity of instruction, psychological environment as factors. Factors may include among others the school environment of the learner. For instance, if the school where the learner attends does not have chemicals in the laboratory, then it will be difficult for that learner to understand chemical reactions (Pfundt \& Duit, 1994). In South Africa, research also indicates that learning science in a second language is a major problem to the understanding of chemical reactions (Nkopodi \& Rutherford, 1990).

The teaching of particulate nature of matter may help learners to develop a better understanding of what happens during chemical reactions. The difference between physical and chemical changes can be illustrated using their particulate descriptions. For example, in chemical change bonds are broken and atoms rearrange to make new molecules whereas in physical change no bonds are broken or formed (Driver, 1985; Driver \& Easley, 1987, Gabel, 1993). Brosnan (1992) suggested that learners often view chemical change differently from a chemist. He further indicated that while the chemist views chemical change as a result of interaction between equal partners, learners often view it as being caused by an active agent acting on a passive substance. Anderson (1986) indicates that this view of an active causal agent is related to the learners' everyday life.

De Vos and Verdonk $(1986,1998)$ reported on the difficulties learners had in classifying chemical reactions as exothermic or endothermic. They found that some learners erroneously referred to, for example, the burning of a candle as an endothermic reaction because heat is needed to initiate the burning process. Johnstone, MacDonald, and Webb (1977) in Singapore reported that their learners held the misconception that endothermic reactions cannot be spontaneous, and that all reactions which occur without overt application of heat are exothermic. Endothermic reaction is the reaction during which energy is absorbed from the surroundings. This means that energy is not necessarily added to endothermic reaction. Instead, energy is absorbed from the surrounding. Exothermic reaction is the reaction during which energy is released to the surroundings (Pienaar, Walters, Schreuder and De Jager, 1986). Thus, understanding chemical reactions is deemed to assist learners to comprehend heat exchange dynamics in their environments and yet learners have many misconceptions regarding the topic.

In Turkey learners difficulties in understanding chemical reactions and energy have been ascribed to the existence of misconceptions on the particulate nature of matter. These include atom, element, compound, molecule, and physical and chemical changes as well as chemical bonds (Ayyildiz \& Tarhan, 2012). Menjo (2012) and Obomanu (2012) contend that in order for learners to meet challenges after school and in everyday life, they should learn chemistry through practical work. This is further confirmed by Chikamori1, Ono1 \& Chikamori1 (2013) that practical work rather than theoretical work is the most useful experience in the years that lies ahead of learners. Cachapuz and Martins (1987) stated that many of their participants in Singapore had misconceptions about energy changes in chemical reactions. A chemical change is a change in which one or more kinds of matter or several new kinds of matter are formed (Ebbing and Gammon, 1999). For example, during the rusting process iron combines with oxygen in air to form a new material called rust. The iron and oxygen combine chemically and cannot be separated by any physical means. In other words, in any chemical change, one or more substances are used up, one or more new substances are formed and energy in the form of heat or light is absorbed or released (Whitten, Gailey and Davis, 1992). This means that when bonds form, attractive forces that enable them to do so tend to decrease the potential energy of the reacting system. When bonds break, on the other hand, particles that may attract each other or repel to break apart. This increases the potential energy of the reacting system. Each reaction, therefore, has an overall energy change. In exothermic chemical reactions, chemical energy is converted into heat energy. In endothermic reactions, heat energy, light energy or electrical energy may be converted to chemical energy (Whitten, Gailey and Davis, 1992). Based on the above information, this study aimed at identifying learners' difficulties in understanding how chemical reactions take place.

\section{Methodology}

A case study approach was used to explain issues in depth and to accumulate sufficient knowledge that would lead to understanding. The case study design was deemed appropriate because it would address the concerns regarding appropriate data for investigating specific research questions (De Vos, 1998). The sample was a comprehensive whole class (Patton, 2002) and it consisted of 40 grade 12 learners: 20 girls and 20 boys. Their average ages ranged between 
17 and 18 years. A five-point Likert scale questionnaire was used. The questionnaire consisted of 20 items where: $1=$ strongly agree; 2 = agree; $3=$ neither agree nor disagree; $4=$ disagree and $5=$ strongly disagree. The first five questions covered chemical bonds, the next five energy changes and the last ten were based on calculations of chemical reactions. Two grade 12 science teachers ascertained face validity of the instruments.

\subsection{Data collection}

Forty respondents were given questionnaires and were asked to rate each of the statements on a five point Likert scale of (1) strongly agree, (2) agree, (3) uncertain, (4) disagree, (5) strongly disagree. The subjects were expected to respond to the questions in the questionnaires without any fear of being identified (McMillan and Schumacher, 2001). This involved simultaneous data collection and analysis (Lincoln \& Cuba, 1985).

\subsection{Data analysis}

Questionnaires were analysed using percentages. Data were grouped into three categories: 1) the responses for "strongly agree" and "agree" were combined to form "agree"; 2) the responses for "disagree" and "strongly disagree" were combined to form "disagree"; and 3) the responses for uncertain and were grouped as "uncertain".

\section{Results}

Results from the questionnaires regarding chemical bonds are presented in Table 1.

Table 1. Responses about bonds in chemical reactions.

\begin{tabular}{|c|c|c|c|c|c|c|c|c|}
\hline Question & \multicolumn{2}{|c|}{ Agree } & \multicolumn{2}{c|}{ Uncertain } & \multicolumn{2}{c|}{ Disagree } & \multicolumn{2}{c|}{ Total } \\
\hline 1. & No & $\%$ & No & $\%$ & No & $\%$ & No & $\%$ \\
\hline 1.1. & 33.0 & 82.5 & 4.0 & 10.0 & 3.0 & 7.50 & 40.0 & 100.0 \\
\hline 1.2 & 28.0 & 70.0 & 7.0 & 17.5 & 5.0 & 1.50 & 40.0 & 100.0 \\
\hline 1.3. & 20.0 & 50.0 & 13.0 & 32.5 & 7.0 & 17.5 & 40.0 & 100.0 \\
\hline 1.4. & 17.0 & 42.5 & 5.0 & 12.5 & 18.0 & 45.0 & 40.0 & 100.0 \\
\hline 1.5. & 27.0 & 67.5 & 7.0 & 17.5 & 6.0 & 15.0 & 40.0 & 100.0 \\
\hline Subtotal & 125.0 & 312.5 & 36.0 & 90.0 & 39 & 97.5 & 200.0 & 500.0 \\
\hline Average & 25.0 & 62.5 & 7.2 & 18.0 & 7.8 & 19.53 & 40.0 & 100.0 \\
\hline
\end{tabular}

From the table, the indication is that majority of respondents agreed to many statements, implying that they understood the involvement of bonds in chemical change. $82.5 \%$ (33) agreed that "during chemical reactions, old bonds are broken and new ones are formed", $10 \%$ (4) were uncertain and $7.5 \%$ (3) disagreed. On the statement that "an ionic bond is a chemical bond formed by the electrostatic repulsion between positive and negative ion", $70 \%$ (28) agreed, 17, 5\% (7) were uncertain and $12.5 \%$ (5) disagreed. For the statement "bond length is the distance between the nuclei of the bonded atoms", 50\% (20) of the respondents agreed, 32.5\% (13) were uncertain and 17.5\% (7) disagreed. Also, 42.5\% (17) of the respondents agreed with the statement that "molecules with weak bonds are harder to separate than molecules with strong bonds", $45 \%$ (18) disagreed and $12.5 \%$ (5) were uncertain.

Table 2 shows the responses to the questions based on energy changes in chemical reactions.

Table 2. Responses about energy in chemical reactions.

\begin{tabular}{|c|c|c|c|c|c|c|c|c|}
\hline Question & \multicolumn{2}{|c|}{ Agree } & \multicolumn{2}{c|}{ Uncertain } & \multicolumn{2}{c|}{ Disagree } & \multicolumn{2}{c|}{ Totals } \\
\hline 2. & No & $\%$ & No & $\%$ & No & $\%$ & No & $\%$ \\
\hline 21. & 29.0 & 72.5 & 7.0 & 17.5 & 4.0 & 10.0 & 40.0 & 100.0 \\
\hline 2.2. & 19.0 & 47.5 & 10.0 & 25.0 & 11.0 & 27.5 & 40.0 & 100.0 \\
\hline 2.3. & 17.0 & 42.5 & 11.0 & 27.5 & 12.0 & 30.0 & 40.0 & 100.0 \\
\hline 2.4. & 9.0 & 22.5 & 14.0 & 35.0 & 17.0 & 42.5 & 40.0 & 100.0 \\
\hline 2.5. & 24.0 & 60.0 & 8.0 & 20.0 & 8.0 & 20.0 & 40.0 & 100.0 \\
\hline Subtotal & 98.0 & 245.0 & 50.0 & 125.0 & 52.0 & 130.0 & 200.0 & 500.0 \\
\hline Average & 19.6 & 49.0 & 10.0 & 25.0 & 10.4 & 26.0 & 40.0 & 100.0 \\
\hline
\end{tabular}


Majority of the respondents seemed to understand the involvement of energy in chemical change. For example, $72.5 \%$ (29) agree that "activation energy is the minimum energy of collision required for two molecules to react", $17.5 \%$ (7) uncertain and $10 \%$ (4) disagreed. Also, $42.5 \%$ (17) of the respondents agreed that "when a chemical system undergoes energy changes, energy absorbed or released is the different between the energy of the system at the end and the energy at the beginning of the reaction", $27.5 \%$ (11) uncertain and 30\% (12) disagreed. $60 \%$ (24) of the respondents agreed to the statement that "it requires more energy to remove an electron from the sodium atom than is gained when the electron is added to the chlorine atom during the formation of sodium chloride", $20 \%$ (8) disagreed and $20 \%$ (8) were uncertain. Other respondents, about 22.5\% (9) agreed with the statement "as the distance between the two nuclei of atoms and the electron cloud that lies between them decrease, the potential difference decreases", 35\% (14) were uncertain and $42.5 \%$ (17) disagreed.

The respondents had different ways of approaching calculations in chemical change (Table 3).

Table 3. Responses about calculations in chemical reactions.

\begin{tabular}{|c|c|c|c|c|c|c|c|c|}
\hline Question & \multicolumn{2}{|c|}{ Agree } & \multicolumn{2}{c|}{ Uncertain } & \multicolumn{2}{c|}{ Disagree } & \multicolumn{2}{c|}{ Totals } \\
\hline 3. & No & $\%$ & No & $\%$ & No & $\%$ & No & $\%$ \\
\hline 3.1. & 15.0 & 37.5 & 13.0 & 32.5 & 12.0 & 30.0 & 40.0 & 100.0 \\
\hline 3.2. & 19.0 & 47.5 & 8.0 & 20.0 & 13.0 & 32.5 & 40.0 & 100.0 \\
\hline 3.3. & 11.0 & 27.5 & 15.0 & 37.5 & 14.0 & 35.0 & 40.0 & 100.0 \\
\hline 3.4. & 13.0 & 32.5 & 13.0 & 32.5 & 14.0 & 35.0 & 40.0 & 100.0 \\
\hline 3.5. & 14.0 & 35.0 & 8.0 & 20.0 & 18.0 & 45.0 & 40.0 & 100.0 \\
\hline 3.6. & 16.0 & 40.0 & 12.0 & 30 & 12.0 & 30.0 & 40.0 & 100.0 \\
\hline 3.7. & 17.0 & 42.5 & 14.0 & 35.0 & 9.0 & 22.5 & 40.0 & 100.0 \\
\hline 3.8. & 15.0 & 37.5 & 13.0 & 32.5 & 12.0 & 30.0 & 40.0 & 100.0 \\
\hline 3.9. & 17.0 & 42.5 & 9.0 & 22.5 & 14.0 & 35.0 & 40.0 & 100.0 \\
\hline 3.10. & 15.0 & 37.5 & 7.0 & 17.5 & 18.0 & 45.0 & 40.0 & 100.0 \\
\hline Subtotal & 152.0 & 380.0 & 112.0 & 280.0 & 136.0 & 340.0 & 40.0 & 100.0 \\
\hline Average & 15.2 & 38.0 & 11.2 & 28.0 & 13.6 & 34.0 & 40.0 & 100.0 \\
\hline
\end{tabular}

In Table 3, 27.5\% (11) of the respondents agreed that considering the hypothetical reaction: A $(\mathrm{g})+\mathrm{B}(\mathrm{g})$ yields $2 \mathrm{C}(\mathrm{g})$ which takes place in a closed $1 \mathrm{dm}^{3}$ container at $400^{\circ} \mathrm{C}$. If the reaction mixture originally contained $4 \mathrm{~g}$ of $\mathrm{A}$ and $5 \mathrm{~g}$ of $\mathrm{B}$, and when equilibrium is reached, it is found that $3.5 \mathrm{~g}$ of $A$ remains unreacted. Assuming that the molar masses of $A$ and $B$ are $12.0 \mathrm{gmol}^{-1}$ and $25.0 \mathrm{gmol}^{-1}$ respectively, the calculated value of the equilibrium constant for the reaction is 0.138 . From respondents, $37.5 \%$ (15) were uncertain and 35\% (14) disagreed. Also, 42.5\% (17) agreed that a cell is composed of a $\mathrm{Be} / \mathrm{Be}+/ / \mathrm{Ag}$ electrodes. By using the table of standard reduction potentials, it was found that the electromotive force (e.m.f) of all is 2.65V, $22.5 \%$ (9) were uncertain and 35\% (14) disagreed. About $47.5 \%$ (19) of the respondents agreed that sulphur trioxide is produced at a temperature of $1000 \mathrm{k}$ according to the equation: $2 \mathrm{SO}_{2}(\mathrm{~g})+\mathrm{O}_{2}(\mathrm{~g})$ yields $2 \mathrm{SO}_{3}(\mathrm{~g})$. If $\mathrm{K}_{\mathrm{c}}=280$ and the equilibrium concentrations are $0.016 \mathrm{~mol} . \mathrm{dm}^{-3}$ for $\mathrm{O}_{2}$ and $0.020 \mathrm{~mol}_{\mathrm{dmm}}{ }^{-3}$ for $\mathrm{SO}_{3}$, then the concentration

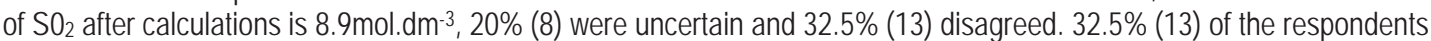
agreed with the statement that $3.65 \mathrm{~g}$ of hydrogen chloride dissolves in $1000 \mathrm{~cm}^{3}$ of water at $25{ }^{\circ} \mathrm{C}$. The concentrations of hydrogen ion and hydroxide ion in the solution are $10^{-13} \mathrm{~mol} \mathrm{dm}^{-3}$ and $0.1 \mathrm{~mol} \mathrm{dm}^{-3}$ respectively, $35 \%$ (14) disagreed and $32.5 \%$ (13) of the respondents were uncertain. Again, $37.5 \%$ agreed that when "one mole of gas is added to two moles of gas $Y$ in a $1 \mathrm{dm}^{3}$ sealed container. Gases $X$ and $Y$ react according to the equation:

$\mathrm{X}(\mathrm{g})+2 \mathrm{Y}(\mathrm{g}) \rightarrow 2 \mathrm{XY}(\mathrm{g}) \Delta \mathrm{H}>\mathrm{O}$.

Calculations involving titrations also were difficult to understand because learners did not follow the steps in answering questions or did not develop a systemic approach in answering questions. For example, they could not write and balance the equation for the reaction as the first step. $40 \%$ of the respondents erroneously agreed that in a titration $30 \mathrm{~cm}^{3}$ of sulphuric acid solution are neutralized by exactly $45 \mathrm{~cm}^{3}$ of sodium hydroxide solution of concentration 0.1 mol.dm-3. The amount (in mol) of sodium hydroxide in the solution is $0.00225 \mathrm{~mol} \mathrm{NaOH}$.

\section{Discussions}

The aim of the study was to identify learners' understanding of chemical reactions and to develop strategies for them to acquire skills on chemical reactions in order to solve real life problems. Whitten, Gailey and Davis (1992) contend that when bonds form, charged particles that attract each other are enabled to do so. These processes tend to decrease the 
potential energy of the reacting system. On the other hand when bonds break, charged particles that normally attract each other are forced apart and this increases the potential energy of the system. This indicates that during the chemical change, bonds are broken and new ones are formed. Results from Table 1 indicate that $82.5 \%$ of the respondents agreed with the fact that "during chemical reactions, old bonds are broken and new ones are formed", $10 \%$ of them being uncertain about the statement and $7.5 \%$ disagreed. This shows that, even though majority of the respondents understood the bond breaking and formation of bonds during chemical change, there are those who have difficulties in understanding how these two reactions take place. The contributing factors in this regard, amongst others, are lack of facilities, like laboratories and Learner Teacher Support Materials (LTSM). This may make it difficult for respondents to understand the concepts in chemical change as corroborated by Pfundt and Duit (1994). Also, respondents are taught in English as a second language and this hinders their understanding. When they write, they fail to express what they observed in acceptable language which decreased their understanding of science concepts and this is in agreement with Rutherford and Nkopodi (1990).

In terms of energy involvement, majority of the respondents seemed to understand how energy is involved in chemical change. Table 2 shows that $72.5 \%$ of the respondents agreed that "activation energy is the minimum energy of collision required for two molecules to react". For example, some of them did not understand what happens with energy during chemical reactions. They did not understand that energy is either absorbed (endothermic reaction) or released (exothermic reaction). $10 \%$ of these respondents were not certain as to whether energy is involved or not during a chemical change. This was because the respondents had misconceptions about energy changes in chemical reactions and this is in agreement with Cachapuz and Martins (1987).

In the case of calculations, results in Table 3 show that respondents had learning difficulties in different sections. For example, in chemical equilibrium, $27.5 \%$ did well and show clear conceptual understanding regarding steps to follow in order to arrive at the expected answer. 35\% had learning difficulties and their answers were wrong. Seemingly the respondents in this section failed to interpret the questions which led to the use of incorrect procedure. For example, respondents just used the formula without considering the proportions between reactants and products. $37.5 \%$ agreed that when "one mole of gas is added to two moles of gas $Y$ in a $1 \mathrm{dm}^{3}$ sealed container. Gases $X$ and $Y$ react according to the equation:

$\mathrm{X}(\mathrm{g})+2 \mathrm{Y}(\mathrm{g}) \rightarrow 2 \mathrm{XY}(\mathrm{g}) \triangle \mathrm{H}>\mathrm{O}$.

If, at equilibrium $1.5 \mathrm{~mol}$ of $\mathrm{XY}$ has formed, the value of $\mathrm{K}$, is 7.2 . When doing calculations, $30 \%$ of the respondents did not get it correct because they would treat this equation as if all the reactants and products are in the same proportions. Some even introduced the equation or formula for calculating the value of $\mathrm{K}_{\mathrm{c}}$ (equilibrium constant) without including the coefficients as exponents. For reduction-oxidation reactions, the respondents did not interpret the table of standard reduction potentials correctly. This made it difficult for them to identify the oxidizing agent and the reducing agent. $42.5 \%$ agreed that a cell is composed of $\mathrm{Be} / \mathrm{Be}^{+} / \mathrm{Ag} / \mathrm{Ag}$ electrodes. Also, $37.5 \%$ of the respondents were not certain on how to start to calculate the asked questions and consequently $\mathrm{n}^{\text {th }}$ question were not attempted. This shows that these respondents did not understand how to solve problems involving chemical changes.

Calculations involving titrations also were difficult for learners because they did not follow the steps in answering questions or did not develop a systemic approach in answering questions. If these respondents started with writing the balanced equation for the reaction, then most likely they would have realized that the number of moles is for the sulphuric acid $\left(\mathrm{H}_{2} \mathrm{SO}_{4}\right)$. It clear from the study that majority of the respondents understand how the breaking of bonds and the formation of bonds could lead to chemical change. Although learners knew that during breaking and forming of bonds energy is either given off or absorbed in the form of heat or light as corroborated by Brady and Holum (1996), but they did know how to explain how such reactions take place.

\subsection{Conclusions and Recommendations}

The findings suggest that the respondents did not do well on chemical change topic. Results were attributed to a number of factors that were not a subject of this study, for instance, poor content knowledge by the teaching staff. Other factors include lack of facilities like laboratories where experiments have to be performed and discussed. The language of teaching and language had a negative impact on learners' understanding of chemistry concepts. This is because respondents barely understand the language in which lesson were presented. Thus, this study recommends the following:

1. Intensive training of teachers to increase their content and English languages levels.

2. Provision of laboratory facilities to all schools in order to improve performance in teaching and learning of chemistry. 


\section{References}

Abrahams I. \& Reiss M.J. (2012). Practical work: its effectiveness in primary and secondary schools in England. Journal of Research in Science Teaching, 49(8), 1035-1055.

Ahtee, M. \& Varjola, I. (1998). Students` understanding of chemical reaction. International Journal of science Education, 20(3), 305-316.

Anderson B. (1986). Pupils' explanations of some aspects of chemical reactions, (Age12-16) Science Education, 70,549-563.

Ayyildiz Y. \& Tarhan L. (2012). The effective concepts on students' understanding of chemical reactions and energy. Hacettepe Üniversitesi Eğitim Fakültesi Dergisi (H. U. Journal of Education) 42, 72-83.

Bless C \& Higson - Smith, C. (1995). Fundamentals of Social Research Methods. An African Perspective. (2 ${ }^{\text {nd }}$ Edition). Kenwyn: Juta and Kie.

Brady, J.E \& Holum, J.R (1996). The Study of Matter and Its Changes. New York: John Wiley \& Sons, Inc.

Brosnan, T. (1992). Explanation of Change. Technical Paper No. 3. University of London, London Mental Models Group, produced for EC Basic Research Actions ESPRIT II. Working Group 6237: Children's and Teachers' Explanations.

Cachapuz, A. F. \& Martins, I. P. (1998). Students` understandings of chemical bonds and the energetics of chemical reactions. Journal of Research in Science Teaching, 35(5), 569-581.

Chikamori1, K. Ono1 Y. \& Rogan J. (2013). A lesson study approach to improving a Biology lesson. African Journal of Research in Mathematics, Science and Technology Education, 17(1-2), 14-25

Dekkers, P. (1997). Making productive use of students` conceptions in Physics Education. Vrije Universiteit Huisdrukkerij.

De Vos, A.S. \& Verdonk, A. (1998). Research at grassroots. Pretoria: van Schaick.

De Vos, W. \& Verdonk, A. (1986). A new road to reactions. Part 3: Teaching the heat effect of reactions. Journal of Chemical Education, 63, 972-974.

Driver, R. (1985). Beyond appearances: The conservation of matter under Physical and Chemical transformations. In R. Driver (Ed.), Children`s ideas in science (pp. 145-169). Philadelphia, PA: Open University Press.

Driver, R. \& Easley, J. (1987). Pupils and paradigms: A review of literature related to concept development in adolescent science students. Studies in Science Education, 5(2), 61-84.

Ebbing, D.D. \& Gammon S.D. (1999). General Chemistry. Houghton: Mufflin Company.

Gabel, D. (1993). Use of the particle nature of matter in developing conceptual understanding. Journal of Chemical Education, 70, 193197.

Johnstone, A.H., MacDonald, J.J. \& Webb (1977). Misconception in school thermodynamics, Physics Education, May 248-251.

Krajcik, J. (1991). Developing students` understanding of chemical concepts. In B. K. Britton (Ed.), The Psychology of Learning Science (pp.117-147).

Lincoln, Y.S. \& Guba, E. G. (1985) Naturalistic inquiry, Beverly Hills, CA: sage publication, Inc.

Mcmillan, J.H. \& Schumecher, S. (2001). Research in education. A conceptual introduction. United States. : Addison Wesley Longman.

Menjo, E. (2012). An Assessment of effectiveness of the secondary school science pedagogy and curriculum relevance to students' needs in Baringo Central, Kenya. Journal of Emerging Trends in Educational Research and Policy Studies (JETERAPS) 4(3), 433-441.

Millar, R. (2010). Analysing practical science activities to assess and improve their effectiveness. Hatfield: Association for Science Education.

Millar, R. (2011). Practical work. In J. Osborne \& J. Dillon (Eds.), Good practice in science teaching: What research has to say (pp. 108134). Maidenhead: Open University Press.

Millar, R. \& Abrahams, I. (2009). Practical work: Making it more effective. School Science Review, 91(334), 59-64.

Nkopodi, N \& Rutherford, M. (1990), International Journal of Science Education, 12(4), 443-456.

Obomanu, B. J. (2012). Teaching fundamentals towards a result-oriented science learning. Journal of Emerging Trends in Educational Research and Policy Studies (JETERAPS) 2 (2), 88-92.

Patton, M.Q. (2002). Qualitative Research and Evaluation methods. Thousand Oaks, Califonia: Sage publication, $3^{\text {rd }}$ Edition.

Pfundt, H. \& Duit, R. (1994). Bibliography-Students` alternative frameworks and science of education. Kiel, Germany: IPN.

Reynolds, A. J., \& Walberg, H. J. (1991). A structural model of science achievement. Journal of Educational Psychology, 83, 97-107.

Whitten, K.W., Gailey, K. D., \& Martins, R. E. (1992). General Chemistry with Qualitative Analysis. London: Saunders College Publishing. 